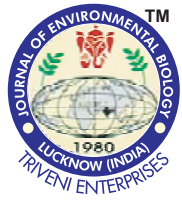

DOI : http://doi.org/10.22438/jeb/39/3/MRN-610

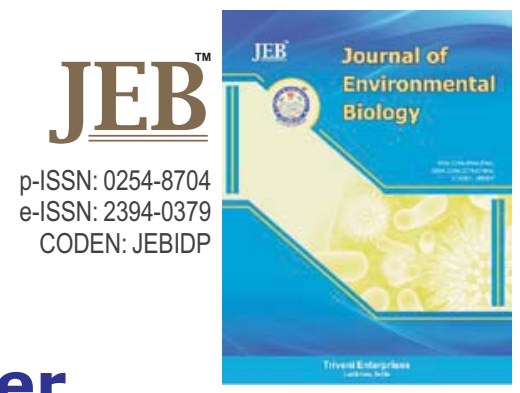

\title{
Assessment of growth, yield, tuber quality and profitability of potato upon boron fertilization
}

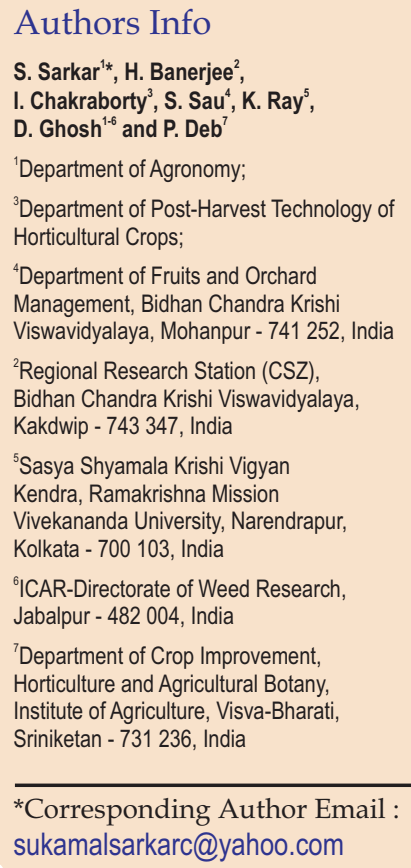

${ }^{*}$ Corresponding Author Email : sukamalsarkarc@yahoo.com

Key words

Alluvial soil

Boron

Foliar nutrition

Potato tuber

Processing-grade potato

Publication Info

Paper received : 08.03.2017

Revised received : 06.08.2017

Re-revised received : 08.09.2017

Accepted : 13.10.2017

\begin{abstract}
\end{abstract}
Aim :The study aimed to investigate the effect of soil and foliar boron fertilization on the growth, productivity and quality well as benefit in processing grade potato (Kufri Chipsona-3) in alluvial soil at West Bengal, India.

Methodology : A field experiment was carried out on alluvial soil at West Bengal during the winter season of 2014-15 and 2015-16. The experiment comprised of five treatments [ $T_{1}$, Recommended dose of fertilizer (RDF) of NPK; $T_{2}, R D F$ of NPK $+2.0 \mathrm{~kg}$ soil applied $B /$ ha; $T_{3}, R D F$ of NPK $+0.1 \%$ boric acid spray at 40 days after planting (DAP); $\mathrm{T}_{4}, \mathrm{RDF}$ of NPK $+0.1 \%$ boric acid spray at 40 and $60 \mathrm{DAP}$; and $\mathrm{T}_{5}, \mathrm{RDF}$ of $\mathrm{NPK}+0.1 \%$ boric acid spray at 40, 50 and $60 \mathrm{DAP}]$ arranged in a completely randomized block design replicated four times. Plant growth, yield, nutrient concentration and quality parameters of potato tuber (specific gravity, total soluble solids, tuber hardness, total acidity, Vitamin C and protein) were analyzed in the experiment.

Results : Experimental findings showed that RDF of NPK $+0.1 \%$ boric acid spray (thrice) produced significantly higher number $\left(3.70 \times 10^{5} \mathrm{ha}^{-1}\right)$ and yield $\left(33.49 \mathrm{tha}^{-1}\right)$ of processing grade tuber than other boron levels (foliar and soil) tested. Application of RDF of NPK $+0.1 \%$ boric acid spray (thrice) exhibited its superiority by producing tubers with significantly higher specific gravity, total soluble solids, tuber hardness, total acidity, Vitamin $\mathrm{C}$, protein and starch content with lowest phenol content and lighter chip colour.

Interpretation : The results of this study indicate that application of boron $(0.1 \%$ boric acid at 40,50 and 60 DAP) in combination with RDF (200 kg N, $150 \mathrm{~K}_{2} \mathrm{O}$ and $150 \mathrm{~kg} \mathrm{P}_{2} \mathrm{O}_{5} \mathrm{ha}^{-1}$ ) is required for optimum yield of processing grade potato (cv. Kufri Chipsona-3) in alluvial Gangetic plains of West Bengal.
Foliar Boron fertilization with $0.1 \%$ boric acid at 40,50 and 60 days after planting

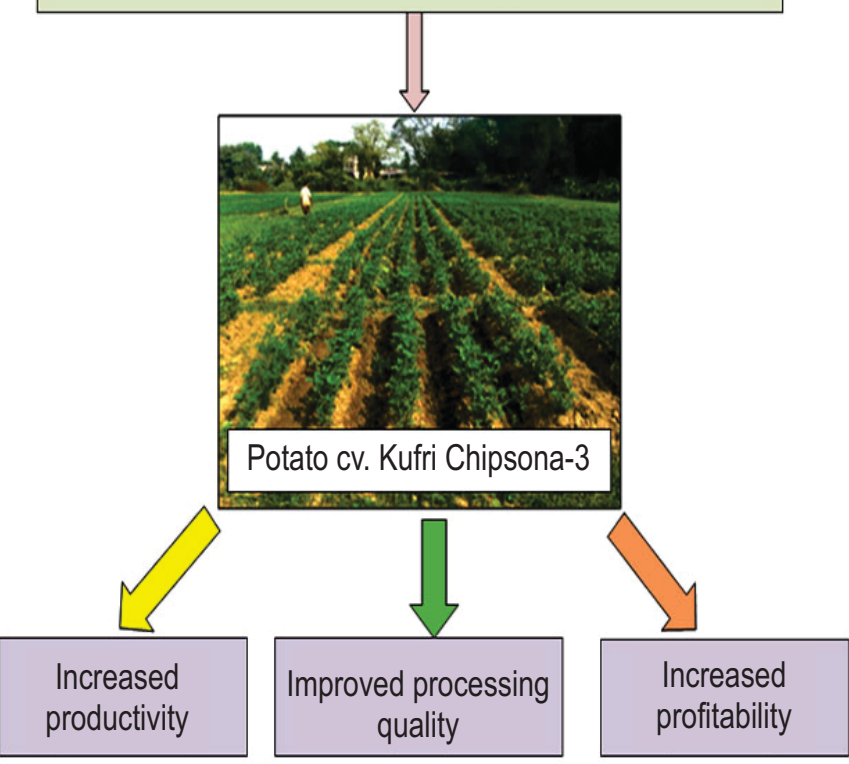




\section{Introduction}

In India, West Bengal ranks second among the potato growing states with a production of 120 lakh tonnes from 4.10 lakh ha, while the productivity was $29.7 \mathrm{t} \mathrm{ha}^{-1}$ during 2013-14 (Horticulture Statistics Division, GOI, 2014). However, for the last few years, potato growers in West Bengal have faced some fundamental setbacks causing over-use of macronutrients ( $N, P$ and $\mathrm{K}$ ) in potato production (Mozumder et al., 2014). Most of the potato growing areas in West Bengal show multi-nutrient deficiencies, resulting in poor yield, low quality of tubers and less profit (Mondal et al., 2015). Adoption of intensive cropping system with high yielding varieties of crops with less or no micronutrient management are the main cause behind this wide-spread micronutrient deficiencies (Banerjee et al., 2016; Raigond et al., 2017). Most of the potato growers of alluvial potato belt of West Bengal largely grow traditional table purpose potato cultivars, which records sub-optimal yield and low market price as these are not suited for processing industries. But, besides culinary consumption, the use of potato has increased progressively for processing purpose (Iritani, 1981). So, for sustaining potato cultivation in these areas introduction of processing-grade potato cultivars is highly important which can meet the industrial needs. For cultivation of processing grade cultivars, tuber quality is imperative to higher yields of potato (Alam et al., 2016; Brown, 2005). Therefore, quality parameters besides higher number and yield of tubers should be taken into consideration so as to meet the customer and industrial demand.

Wide-spread boron deficiency is an emerging constraint to crop production next to zinc and it has emerged as an important micronutrient in Indian agriculture (Sathya et al., 2009). Boron is an essential micronutrient required for growth and development of crop plants (Singh et al., 2014). Its deficiency exerts adverse effects on yield and quality of the crops. In most cases, adverse effects of boron omission can occur on the yield even when no deficiency symptoms are evident on the foliage and it is known as 'hidden hunger'. Significant reaction of potato to the applied boron-fertilization has been largely observed on boron-deficient soil (Sathya et al., 2009). Being a highly boron responsive crop, yield and quality of potato is greatly influenced by the boron nutrition (Hazra et al., 2012). Boron application in potato helps to improve the dry matter and starch (Khan et al., 2010) which are considered as essential quality parameters for processing, particularly for preparation of 'Chips' and 'French fries' (Adams, 2004). Boron in plants is reported to function at membrane level by maintaining membrane integrity and enhanced ability of membrane to transport vital nutrients (Shelp et al., 1995; Cakmak et al., 1995). Boron fertilization has positive impact on catalase and ascorbic acid content in fresh potato tuber (Li et al., 2002). Foliar fertilization to potato with boron has significant impact on the amino acid content, especially increased methionine content in tuber (Kozera et al., 2003). Boron exerts positive effect on improving frying quality of potato by reduction of reducing sugar and total phenol content (Lora Silva et al., 2008). Keeping in view the above mentioned facts, a two-year-experiment was conducted with the objectives to assess the effects of boron fertilization on yield, tuber quality, and to provide insights into the benefits of applying boron in potato cultivation.

\section{Materials and Methods}

The experiment was conducted in the winter season of 2014-15 and 2015-16 at District Seed Farm-C Unit under Bidhan Chandra Krishi Viswavidyalaya, West Bengal, India. The soil on the research site was sandy clay loam in texture and had the following key properties for the $0-30 \mathrm{~cm}$ layer: $\mathrm{pH} 7.35$, EC 0.25 $\mathrm{dS} \mathrm{m}^{-1}$, organic carbon $0.10 \%$, available $\mathrm{N} 82.1 \mathrm{~kg} \mathrm{ha}^{-1}$, available P 78.3 kg ha ${ }^{-1}$, available $\mathrm{K} 193.2 \mathrm{~kg} \mathrm{ha}^{-1}$ and available B $0.55 \mathrm{mg}$ $\mathrm{kg}^{-1}$. Maximum and minimum temperature ranged between 37.3$24.8^{\circ} \mathrm{C}$ and $20.3-9.6^{\circ} \mathrm{C}$ in $2014-15$ and $35.1-23.7^{\circ} \mathrm{C}$ and 21.8 $9.3^{\circ} \mathrm{C}$ in $2015-16$. Relative humidity prevailed between 89 and $34 \%$ in 2014-15, and 97 and $34 \%$ in 2015-16. The rainfall during the experimental period (November to March) was recorded 24.2 (5 rainy days) and $112.3 \mathrm{~mm}$ (14 rainy days) in 2014-15 and 201516 , respectively. Maximum bright sunshine recorded was 144.7 hrs in 2014-15 and $113 \mathrm{hrs}$ in 2015-16.

The experiment comprised of five treatments $\left[T_{1}\right.$, Recommended dose of fertilizer (RDF) of NPK; $\mathrm{T}_{2}, \mathrm{RDF}$ of NPK + $2.0 \mathrm{~kg}$ soil applied $B$ ha ${ }^{-1} ; T_{3}, R D F$ of NPK $+0.1 \%$ boric acid spray at 40 days after planting (DAP); $\mathrm{T}_{4}, \mathrm{RDF}$ of NPK $+0.1 \%$ boric acid spray at 40 and $60 \mathrm{DAP}$; and $\mathrm{T}_{5}, \mathrm{RDF}$ of NPK $+0.1 \%$ boric acid spray at 40,50 and $60 \mathrm{DAP}$ ] arranged in a completely randomized block design replicated four times. Each plot measured $5.0 \mathrm{~m}$ in width and $4.0 \mathrm{~m}$ in length with a space of $0.5 \mathrm{~m}$ between plots. The test crop was potato cv. Kufri Chipsona-3, a medium maturing (harvest maturity in 110 days), late blight resistant, high dry matter and low reducing sugar content with round oval tubers, white smooth skin and cream/pale yellow flesh. The variety is meant for processing, especially chip making, and is an improvement over the existing varieties Kufri Chipsona-1 and 2. Seed potato tubers weighing about $30-40 \mathrm{~g}$ were hand planted on 26 and 25 November in 2014 and 2015, respectively on furrows opened by tyne at a spacing of $60 \mathrm{~cm} \times 20 \mathrm{~cm}$ and depth of $15 \mathrm{~cm}$, and finally covered with soil. A uniform recommended dose of $\mathrm{N}: \mathrm{P}_{2} \mathrm{O}_{5}: \mathrm{K}_{2} \mathrm{O}$ at 200:150:150 kg ha ${ }^{-1}$ (Department of Agriculture, GoWB, 2012) was applied in all the plots through urea ( $50 \%$ before sowing and $50 \%$ at $30 \mathrm{DAP})$, single super phosphate ( $100 \%$ before sowing), and muriate of potash (100\% before sowing). Granubor Natur (produced and marketed by Zuari Agro Chemicals Limited, Chidambaram, Tamil Nadu) containing $15 \%$ B and $0.1 \%$ boric acid solution (containing 17\% B) used as a source of soil and foliar applied boron fertilizer, respectively. After dehaulming, the test crop was manually harvested from the middle row $(4.0 \mathrm{~m}$-long) in each plot on 10 and 11 March in 2015 and 2016, respectively.

Germination percent was recorded at 25 DAP. Other biometric observations namely plant height, LAl, number of 
shoots/plant and compound leaves/plant were recorded at 100, 75, 100 and 75 DAP, respectively. At harvest, the dry weight of haulm and tuber was recorded separately and finally whole plant (haulm + tuber) dry weight is given. Following harvest, potato tubers were graded and assessed for processing grade (weight > $100 \mathrm{~g}$ ) and total yield.

The economic parameters like gross returns, net returns and incremental cost-benefit ratio (ICBR) were calculated as per the following formula given by Sheoran et al. (2013).

$$
\begin{aligned}
& G R=Y_{S} \times P_{S} \\
& N R=G R-T C P \\
& I C B R=\frac{G R_{T}-G R_{R D F}}{T C P_{T}-T C P_{R D F}}
\end{aligned}
$$

Where, GR, gross return in Rs. ha ${ }^{-1} ; Y_{s}$, tuber yield in $t$ ha ${ }^{-1} ; P_{s}$, minimum support price of potato in Rs. $t^{-1} ; N R$, net return in Rs. ha ${ }^{-1} ; \mathrm{TCP}$, total cost of production; ICBR, incremental cost-benefit ratio; $\mathrm{GR}_{\mathrm{T}}$, gross return of the treatment for which ICBR was calculated; $G_{\mathrm{RDF}}$, gross return of the RDF treatment; $\mathrm{TCP}_{\mathrm{T}}$, total cost of production with the treatment for which ICBR was calculated; $\mathrm{TCP}_{\mathrm{RDF}}$, total cost of production of the RDF treatment.

Total nitrogen concentration from potato tubers was determined by Micro-Kjeldahl steam distillation method (AOAC, 2000). Phosphorus and potassium concentration of potato tuber were determined in digests of tri-acid mixture (Jackson, 1973). Boron uptake in tuber was estimated through azomethine-H colorimetric method (Gaines and Mitchell, 1979).

The total soluble solids (TSS) content of potato was quantified with the help of a digital refractometer. The total titratable acidity was determined by volumetric procedure (AOAC, 2000). Ascorbic acid (Vitamin C) content of the potato was estimated by using 2, 6 di-chlorophenolindophenol dye titration method (Casanas et al., 2002). The total soluble sugar and total starch (dry weight basis) of potato tuber was determined by universal anthrone reagent method as stated by Sen et al. (2006). The concentration of total phenol content from fresh potato tuber was estimated with the help of Folin-Ciocalteau reagent (Singleton et al., 1999). Protein content (\%) of the potato tuber was estimated by multiplying total nitrogen content by 6.25 (Sadasivam and Manickam, 1996). Specific weight of potato was determined by hydrometer method (Gould, 1999). Tuber hardness of potato was determined by a Screw type Penitrometer. Evaluation of chip colour was based on a scale of 1 to 10 , subjectively with the help of the colour cards (Ezekiel et al., 2003b), where 1 denotes a highly acceptable colour and 10 denotes a dark brown and unacceptable colour. Chips with colour range of 1.0-3.0 were considered acceptable.
Statistical analysis was performed by analysis of variance (ANOVA) in a randomised block design (RBD) using SAS software version 9.2 applying analysis of variance (PROC GLM) with subsequent multiple comparisons of means for both of the experimental years.

\section{Results and Discussion}

No significant impact of boron application (either through soil or foliar application) was observed on germination percentage, plant height, leaf area index, shoots per plant and compound leaves per plant. Data in Table 1 revealed that there was no significant improvement in dry weight for haulm, tuber as well as whole plant (haulm + tuber) with boron application. These findings reflect low requirement of boron for vegetative growth of potato crop than reproductive growth (Dell and Huang, 1997). Therefore, the plants can show poor yield without exhibiting other symptoms, due to no boron application (Rerkasem et al., 1993).

Boron fertilization had significant positive impact on tuber number as well as potato yield (Table 2); this holds true both for processing grade as well as total tuber yields. The treatment RDF of NPK $+0.1 \%$ boric acid sprays (thrice) produced maximum number of total tubers $\left(4.44 \times 10^{5} \mathrm{ha}^{-1}\right)$ as well as processing grade tuber $\left(3.70 \times 10^{5} \mathrm{ha}^{-1}\right)$ and it was significantly higher than other boron levels (foliar and soil) tested. The same treatment resulted in maximum processing grade tuber ( $33.49 \mathrm{tha}^{-1}$ ) as well as total tuber yield $\left(35.05 \mathrm{t} \mathrm{ha}^{-1}\right)$ accounting 35.5 and $34.7 \%$ increase than control (RDF of NPK only). Singh et al. (2014) also recorded higher yield of tubers and increased tuber size with combined application of NPK and boron, which might be due to either direct or cumulative effect of supplied macro and micronutrients on metabolic activities of potato. This can also be partially explained by the fact that higher uptake of this nutrient in reproductive tissues results in increased metabolic activities by increasing RNA and DNA contents (Sathya et al., 2009), ultimately resulting in increased translocation of photosynthates from the source to sink i.e. tubers (Singh et al., 2014). Foliar boron fertilization provided a continuous supply of plant nutrient for a longer period of crop growth or when required by the plants, which possibly facilitates a steady translocation of the photosynthates resulting in higher crop yield than soil application. Also, foliar applied micronutrient in readily available form, especially boron, faces less resistance as compared to the soil applied ones, which might have to compete with other antagonistic macronutrients i.e. phosphorus, to reach the absorption site of root in available form (Bhattacharyya et al., 2015).

Application of $0.1 \%$ boric acid spray (thrice at 40,50 and 60 DAP) in combination with RDF of NPK was found to be the most effective dose, with highest net return (Rs. $143 \times 10^{3}$ ha $^{-1}$ ) and ICBR (45.5). Both net return and ICBR was low in control (-B) and single spray of $0.1 \%$ boric acid. 


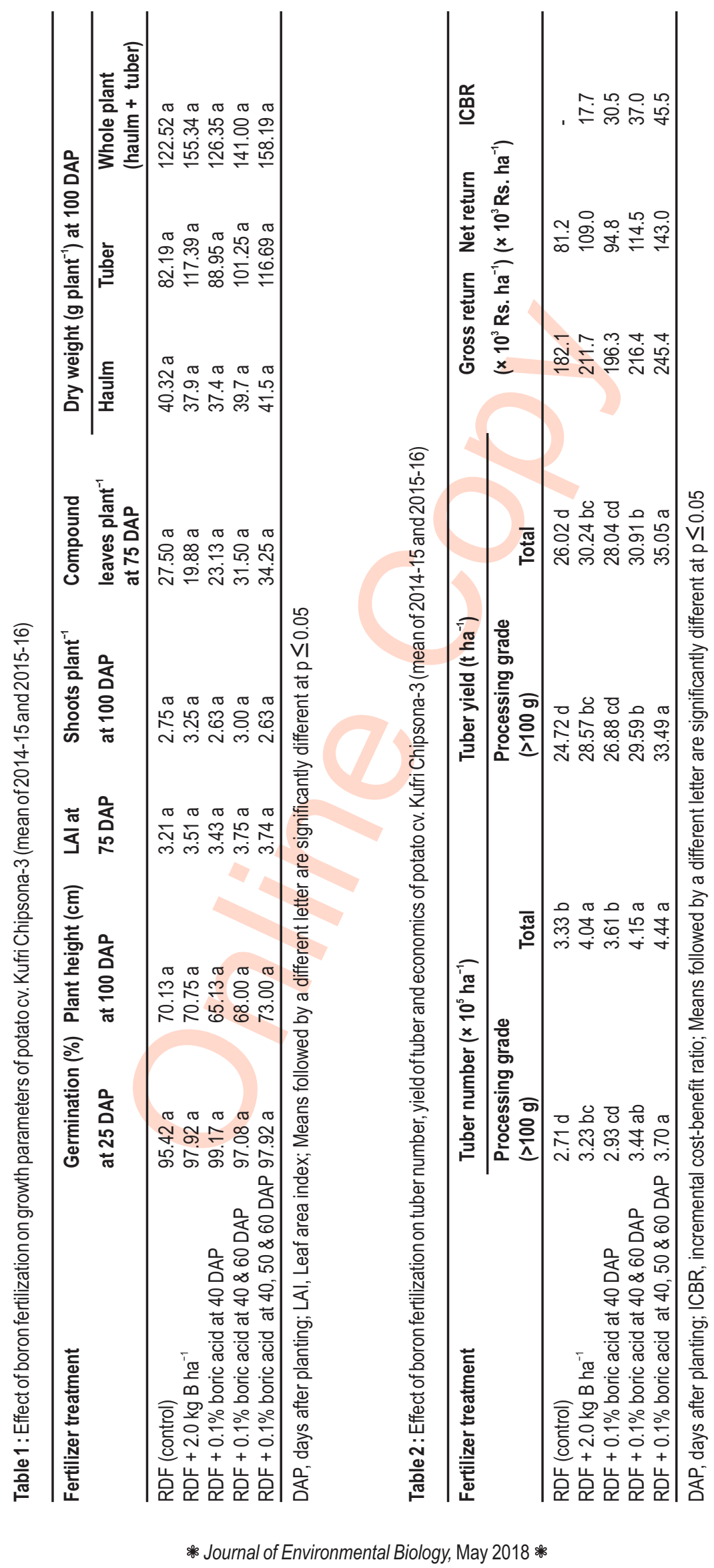


Nutrient (N, $\mathrm{P}$ and $\mathrm{B})$ concentration in potato tuber was significantly promoted by boron application (Table 3), but the effect was non-significant for potassium concentration. Tuber boron contents obtained the maximum value $(85.8 \%$ more than control) with RDF of NPK $+0.1 \%$ boric acid spray (thrice) and this was significantly higher than the values obtained with other treatments. The same treatment recorded highest nitrogen concentration ( $75 \%$ more than control) and least phosphorus uptake $(72.1 \%$ less than control) in potato tuber. Increased concentration of nitrogen as influenced by increasing concentration of boron in potato tuber have also been supported in previous study where significant positive interaction of boron with nitrogen in potato crop was found (Singh et al., 2014). ElDissoky and Abdel-Kadar (2013) suggested the possible cause of higher nitrogen-uptake in potato tuber with boron application as it plays significant role in synthesis of amino acids and proteins. Decrease in phosphorus concentration with boron application in potato crop indicating an antagonistic effect of phosphorus with applied boron may be attributed to hindrance in the absorption and translocation of phosphorus from the roots to the above ground parts, caused by increased concentration of boron (Bhattacharyya etal., 2015).

The quality parameters namely specific gravity, total soluble solids, tuber hardness, total acidity and vitamin $\mathrm{C}$ content of potato tubers were significantly affected with boron application (Table 4). The potato tubers obtained from the plants treated with foliar boron had higher quality attributes than those harvested from the plants treated with soil applied boron. Tubers harvested from the plants treated with RDF of NPK $+0.1 \%$ foliar spray at 40 , 50 and 60 DAP exhibited significantly higher specific gravity, TSS, tuber hardness, total acidity and Vitamin $\mathrm{C}$ content, accounting 1.87, 51.4, 33.9, 21.9 and $20.2 \%$ more than the potatoes harvested from control plots (Only NPK, without B). Boron plays an important role in the translocation of carbohydrates from leaves to other parts of the plant. Therefore, greater concentration of ascorbic acid may have been translocated to the tuber as a result of boron application (Mondy and Munshi, 1993), which makes the tubers more nutritious. Statistical analysis in the present study did not show any significant variation in total dry matter content in tubers with boron fertilization. The same treatment (RDF of NPK $+0.1 \%$ boric acid spray thrice) proved to the best by producing tubers with significantly higher protein content and total starch content, accounting 70.8 and $23.2 \%$ more than control (without boron). According to Sathya et al. (2009), boron improves photosynthetic activity, enhances activity of enzymes and plays a significant role in protein and nucleic acid metabolism. Bandana et al. (2016) holds the view that crisp texture of potato tuber depends mainly upon the starch content. High starch content forms more gelatinization during processing of tubers, and thereby contributes to desirable texture. Findings of the present study indicate reduction of total soluble sugar content in potatoes with boron application and more acceptable tubers are produced with foliar application of boron (thrice). Low sugar content in tubers is considered acceptable for producing chips, while processed products from potatoes with high sugar (as obtained from control plots) turn brown or black, and finally becomes unacceptable (Mondal et al., 2015). In the present study, boron application was also effective in reducing the phenolic concentration in tubers and significantly lowest total phenol content was recorded in potatoes harvested from the plants fertilized with RDF of NPK $+0.1 \%$ boric acid spray thrice ( $60 \%$ less than control). This result is in agreement with the findings of Mondy and Munshi (1993) who suggested that boron could have restricted the influx of substrate into pentosephosphate pathway and synthesis of phenols, thereby reducing the total phenolic concentration in tuber. While, Goldbach (1997) suggested that under boron-deficiency the use of carbohydrates for the deposition of cell wall material is likely to be inhibited. This close temporal association between boron-deficiency and increased phenol concentration has also been observed in the present study. In addition, boron application significantly improved the potato chip colour. Potatoes harvested from plants fertilized with RDF of NPK $+0.1 \%$ boric acid spray at 40,50 and 60 DAP recorded lighter chip colour than those harvested from plants fertilized with any other boron application (73.2\% lighter than control). However, reduction of boron foliar sprays up to two or one resulted in non-significant increase in chip colour of potato. Soil application of boron was less effective in producing lighter chip colour than foliar sprays, and it was statistically at par with boron omission treatment (RDF of NPK only). According to Bandana et al. (2016), the phenolic concentration in tubers influence colour development in processed potato products and the desirable chip colour can only be obtained with low phenol content in tubers.

The correlation studies between boron uptake in tuber and quality traits suggested that boron concentration in tuber had significant and positive correlation with specific gravity $\left(R^{2}=\right.$ $0.950, P=0.01)$, tuber dry matter $\left(R^{2}=0.822, P=0.05\right)$, protein $\left(\mathrm{R}^{2}=0.934, P=0.01\right)$, TSS $\left(\mathrm{R}^{2}=0.861, P=0.05\right)$, vitamin $\mathrm{C}\left(\mathrm{R}^{2}=\right.$ $0.976, P=0.01)$ and total starch $\left(R^{2}=0.913, P=0.05\right)$. On the other hand, significant and negative correlations were observed between $B$ uptake in tuber and chip colour $\left(R^{2}=0.821, P=0.05\right)$. The relationships between boron uptake in tuber and quality parameters suggest that an increase of tuber boron could promote these parameters. This also indicates that these quality characters were governed by the same genetic system i.e. the characters were expected to be linked with each other and they should be given high priority during selection of high yielding genotypes of processing-grade potato. The most pertinent observation was that chip colour improves with subsequent decrease in phenol content. Comparably, higher phenol content was inversely proportional to sugar content of tubers. Therefore, 
S. Sarkar et al.
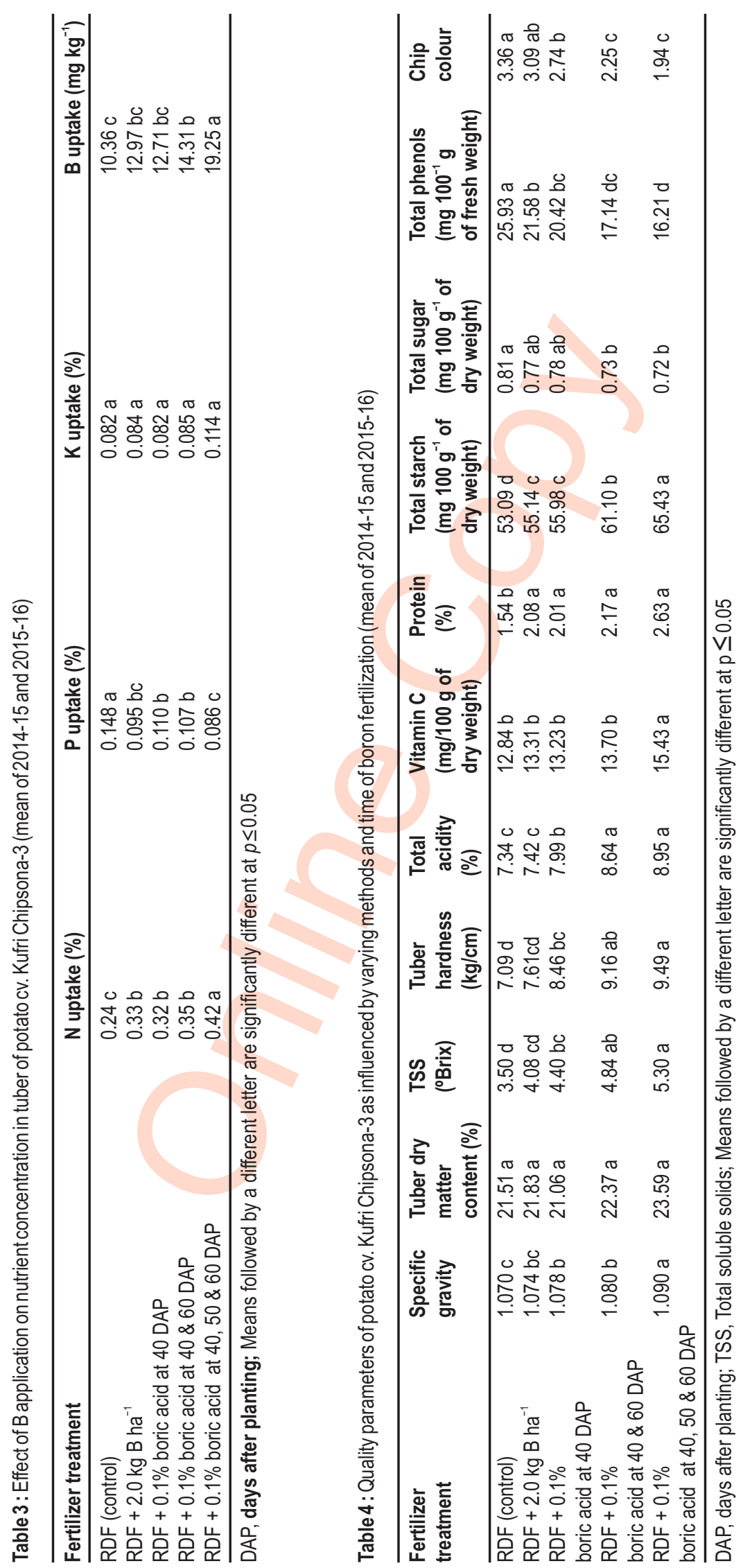
with higher boron rates, reducing sugars in potatoes decreases and chip colour improves (Ezekiel et al., 2003a).

Considering the yield, economics, tuber quality and nutrient uptake, it may be concluded that B application $(0.1 \%$ boric acid at 40, 50 and $60 \mathrm{DAP})$ in combination with RDF $(200 \mathrm{~kg}$ $\mathrm{N}, 150 \mathrm{~K}_{2} \mathrm{O}$ and $150 \mathrm{~kg} \mathrm{P}_{2} \mathrm{O}_{5} \mathrm{ha}^{-1}$ ) is beneficial for processing grade potato (cv. Kufri Chipsona-3) in alluvial Gangetic plains of West Bengal.

\section{Acknowledgments}

Bidhan Chandra Krishi Viswavidyalaya and ICAR-Central Potato Research Institute of India are acknowledged for financial support of this study.

\section{References}

Adams, J.B.: Raw materials quality and the texture of processed vegetables. In: Texture in Foods: Solid Foods; (Ed.: D. Kilcast) Cambridge, UK., pp. 342-363 (2004).

Alam, S., N. Islam, J. Hossain, M. Islam, S.R. Bhuiyan and I. Hossain: Optimizing crop geometry for processing-grade tuber yield, quality and economics of potato in Grey Terrace Soil. Arch. Agron. Soil Sci., 62, 1-12(2016).

AOAC: Official methods of Analysis. $17^{\text {th }}$ Edn., Association of Official Analytical Chemist, Arlington, VA(2000).

Bandana, V. B. Sharma, B. Singh, P. Raigond and S. K. Kaushik : Role of invertase activity in processing quality of potatoes: Effect of storage temperature and duration. J. Environ. Biol., 37, 239-245 (2016).

Banerjee, H., L. Rana, K. Ray, S. Sarkar, K. Bhattacharyya and S. Dutta: Differential physiological response in potato (Solanum tuberosum L.) upon exposure to nutrient omissions. Indian J. Plant Physiol., 21, 129-136 (2016).

Bhattacharyya, K., J. Mandal, H. Banerjee, A. Alipatra, K. Ray and A. Phonglosa: Boron fertilization in sunflower (Helianthus annuus L.) in an inceptisol of West Bengal, India. Commun. Soil Sci. Plant, 46, 528-544 (2015).

Brown, C.R.: Antioxidants in potato. Am. J. Potato Res., 82, 163-172 (2005).

Cakmak, I., H. K urtz and H. Marschner: Short-term effects of boron, germanium and high light intensity on membrane permeability in boron deficient leaves of sunflower. Physiol. Plantarum, 95, 11-18 (1995).

Casanas, R., M. González, E. Rodríguez, A. Marrero and C. Díaz: Chemometric studies of chemical compounds in five cultivars of potatoes from Tenerife. J. Agr. Food Chem., 50, 2076-2082 (2002).

Dell, B. and L. Huang: Physiological response of plants to low boron. Plant and Soil, 193, 103-120 (1997).

Department of Agriculture, GoWB: Economic Review. Evaluation Wing, Directorate of Agriculture, West Bengal, p. 65 (2012).

El-Dissoky, R.A. and A.E.S. Abdel Kadar: Effect of boron as a foliar application on some potatoes cultivars under Egyptian alluvial soil conditions. Res. J. Agri. Biol. Sci., 9, 232-240 (2013).

Ezekiel, R., A. Mehta, D. Kumar and M. Das: Potato storage. In: The Potato Production and Utilization in Sub-Tropics. New Delhi, India, pp. 323-335 (2003b).
Ezekiel, R., B. Singh and D. Kumar: A reference chart for potato chip colour for use in India. J. Indian Pot. Asso., 30, 259-265 (2003a).

Gaines, T.P. and G.A. Mitchell: Boron determination in plant tissue by the azomethine H method. Commun. Soil Sci. Plant, 10, 1099-1108 (1979).

Goldbach, H.E.: A critical review on current hypotheses concerning the role of boron in higher plants: suggestions for further research and methodological requirements. J. Trace Microprobe T., 15, 51-91 (1997).

Gould, W.A.: Specific gravity of potatoes. In: Potato Production, Processing and Technology. CTI Publications Inc., Maryland, USA, p.72 (1999).

Hazra, G.C., B. Saha and B. Mandal : Micronutrient Research in West Bengal. Directorate of Research, Bidhan Chandra Krishi Viswavidyalaya, Mohanpur, West Bengal, India, p. 1-73 (2012).

Horticulture Statistics Division. Department of Agriculture \& Cooperation, Government of India. [Data accessed on 1st August, 2016]. Web site: http://www.agricoop.nic.in/AdminAgricoop/Uploaded_File IICAR_5.pdf(2014).

Iritani, W.M. : Growth and pre-harvest stress and processing quality of potatoes. Am. Potato J., 58, 71-80 (1981).

Jackson, M.L. : Soil Chemical Analysis. Prentice Hall of India Pvt. Ltd., New Delhi, India (1973).

Khan, M.Z., M.E. Akhtar, M.N. Safdar, M.M. Mahmood, S. Ahmad and N. Ahmed: Effect of source and level of potash on yield and quality of potato tubers. Pakistan J. Bot., 42, 3137-3145 (2010).

Kozera, W., K. Nowak and W. Cwojdzinski: Effect of fertilization with some microelements on the content and quality of potato tuber protein. Acta Sci. Polonorum. Agricultura (Poland), 22, 73-82 (2003).

Li, J., X.D. Li and D. Zhang: Effects of B and Mo on tuber yield and active oxygen metabolism in potato (Solanum tuberosum L). Chinese Potato J., 16, 10-13 (2002).

Lora Silva, R., A.P. López Alayón, R. Gómez and H. Bernal: Effect of doses of $\mathrm{Fe}, \mathrm{Cu}, \mathrm{Mn}, \mathrm{Zn}, \mathrm{B}$ and $\mathrm{Mo}$ on reducend and total sugars and on fried quality on creole potato (Solanum phureja). Rev UDCAActualidad and Divulgación Científica, 11, 163-73 (2008).

Mondal, S.S., B.C. Patra and H. Banerjee. Micronutrient management. In: Advances in Potato Cultivation Technology Kalyani Publishers, India, pp. 115-121 (2015).

Mondy, N.I. and C.B. Munshi: Effect of boron on enzymic discoloration and phenolic and ascorbic acid contents of potatoes. J. Agr. Food Chem., 41, 554-556 (1993).

Mozumder, M., H. Banerjee, K. Ray and T. Paul: Evaluation of potato (Solanum tuberosum) cultivars for productivity, $\mathrm{N}$ requirement and eco-friendly indices under different nitrogen levels. Indian $\mathrm{J}$. Agron., 59, 327-335 (2014).

Raigond, P., B. Raigond, B. Kaundal, B. Singh, A. Joshi and S. Dutt. Effect of zinc nanoparticles on antioxidative system of potato plants. J. Environ. Biol., 38, 435-439 (2017).

Rerkasem, B., S. Netsangtip and C. Cheng: Grain set failure in borondeficient wheat. Plant and Soil, 155, 309-312 (1993).

Sadasivam, S. And A. Manickam: Biochemical Methods. New Age International Pvt. Ltd., New Delhi, pp. 11-12(1996).

Sathya, S., G.J. Pitchai and R. Indirani: Boron nutrition of crops in relation to yield and quality-a review. Agric. Reviews, 30, 139-144 (2009).

Sen, S., A. Bhattacharya, D. Mazumdar, H. Sen, A.K. Das and S. Pal: Nutrient and antinutrient composition of cormels of Colocasia esculenta var. antiquorum. J. Veg. Sci., 11, 17-33 (2006). 
Shelp, B.J., E. Marentes, A.M. Kitheka and P. Vivekanandan. Boron mobility in plants. Physiol. Plantarum, 94, 356-361 (1995).

Sheoran, P., V. Sardana, S. Singh, O. P. Sheoran and D. Raj. Optimizing sulphur application in sunflower (Helianthus annuus) under irrigated semi-arid tropical conditions. Indian J. Agron., 58, 384-390 (2013).

Singh, S., D. Kumar, B. S. Chandel and V. Singh: Effect of balanced fertilization on yield, nutrients uptake and economics of potato (Solanum tuberosum) in alluvial soil. Indian J. Agron., 59, 451-454 (2014).

Singleton, V.L., R. Orthofer and R.M. Lamuela-Raventos: Analysis of total phenols and other oxidation substrates and antioxidants by means of Folin-Ciocalteu reagent. Method Enzymol., 299, 152-178(1999). 